\title{
Extended Kin and Children's Behavioral Functioning: \\ Family Structure and Parental Immigrant Status
}

\author{
Jeehye Kang, Old Dominion University \\ Philip N. Cohen, University of Maryland
}

Accepted at Social Science \& Medicine, April 17, 2017

\begin{abstract}
Using the Los Angeles Family and Neighborhood Survey (L.A. FANS), this paper examines the association between the presence of co-resident extended kin and children's internalizing and externalizing behaviors. The paper demonstrates the differential role of extended kin by family structure, as well as across parental immigrant status - specifically, nativity and documentation status. Children in the sample were found to be disadvantaged in extended family households, especially with regard to internalizing behaviors. This disadvantageous association was found mostly among married-parent extended family households, whereas there was no association between the presence of extended kin and behavior problems in children from single-parent families. This pattern emerged more clearly among children of documented immigrants, compared to those with native-born parents and those whose parents were unauthorized immigrants. These findings suggest a need to modify previous theories on extended family living arrangements; they also provide policy implications for immigrant families.
\end{abstract}

Keywords Children; Extended household; Family structure; Immigrants; Internalizing and externalizing behavioral problems; Undocumented 


\section{Extended Kin and Children's Behavioral Functioning: \\ Family Structure and Parental Immigrant Status}

\section{BACKGROUND}

Families provide the most influential contexts for children's development (Bornstein, 2002). Previous research has focused on the disadvantages of single-parent families compared to married-parent families (discussed below). However, little is known about the influence of extended kin on child development. Children organize their emotions and behaviors in response to social experiences (Gross 2007), and extended family members can change the nature of relationships, as well as the amount and distribution of resources within the household (Jacobsen, Mather, \& Dupuis, 2012). Thus, we need to identify how extended kin are associated with child emotional and behavioral development.

The influence of extended kin on children may be different by family structure, and across parental immigration status. In single-parent families, extended family members are more likely to provide resources to the host family, while they tend to receive support in marriedparent families (Jayakody, Chatters, \& Taylor, 1993). Many immigration scholars believe the provision of support from extended families is stronger for immigrants due to familism (discussed below). However, structural constraints may hinder immigrant families from properly functioning in this way (Menjívar 2000; Viruell-Fuentes, Morenoff JD, Williams DR, \& House JS, 2013), partly due to asymmetric exchange relationships between the family and extended kin in migration networks (Brown, 2007; Vallejo, 2012). This hindrance may be even pronounced for unauthorized immigrants, due to their limited access to resources that require identification (Bean, Brown, \& Bachmeier, 2015; Suárez-Orozco, Teranishi, Suárez-Orozco, \& Yoshikawa, 
2011; Yoshikawa, 2011). In other words, family structure, parental nativity and documentation status may differently affect the direction and quality of exchange relationships within extended family households, and thus these factors should be considered in understanding the role of extended kin on child development.

This paper examines the association between co-residence with extended kin and children's internalizing and externalizing behaviors for native, documented immigrant, and unauthorized immigrant families, as well as how family structures moderate the role of extended kin. We focus on internalizing and externalizing behaviors because they are more immediately responsive to social and emotional experiences in families than are other developmental outcomes, such as cognitive ability. Children with emotional and behavioral disorders are more likely to engage in risky behavior, experience relational hardship (Fanti \& Henrich, 2010), and fail to graduate from high school (McLeod \& Kaiser, 2004) if they do not receive adequate intervention. Internalizing and externalizing problem behaviors are often co-morbid, yet relate to different emotions and regulations (Eisenberg, Fabes, Guthrie, and Reiser 2000); thus, we examine both outcomes. By doing so, we identify the domains in which extended kin are more influential, to aid in consideration of effective interventions.

Childhood is a significant period in the life course, as individual trajectories set in this period may be retained over adolescence and beyond (García Coll and Marks 2009). To pinpoint the family's influence on children during a crucial developmental stage, we chose to study children in early and middle childhood (García Coll et al., 1996). Younger children are more susceptible to both negative and positive experiences; thus, these children stand to gain the most from interventions (Hertzman 2013). 


\section{PREVIOUS RESEARCH}

Family structures are an important mechanism for understanding children's risk and resilience. It is known that single-parent families are disadvantaged in terms of financial security and relational resources, compared to married-parent families (McLanahan and Sandefur 1994; Wen 2008). Research shows that children in single-parent families fare worse in terms of their cognitive and behavioral outcomes, relative to those in married-parent families (Barrett \& Turner 2005; Carlson \& Corcoran, 2001).

However, the implications for children of co-resident extended kin are less clear. On one hand, extended family members can provide additional material, human, and social capital resources (Castiglia, 1999; Hofferth, Boisjoly, \& Duncan, 1998). With additional income from extended kin, parents may feel less constrained in paying for housing, energy, food, and other consumable goods; thus, they may invest more time, money and energy in caring for and monitoring their children. Emotional support, instruction, and social regulation by extended family members mitigate stress for mothers (Wilson, 1989, p. 380) and provide a sense of security for children (Castiglia 1999). Also, child care provided by extended kin can relieve mothers both financially and emotionally (Cohen, 2002; DeLeire \& Kalil, 2002; Edin \& Lein, 1997; Tienda \& Glass, 1985), which may also benefit children. Extended kin are positively associated with child development in some studies (Dunifon \& Kowaleski 2007; Foster \& Kalil, 2007).

On the other hand, extended family members may require resources and increase family stress. Extended family members can be a source of stress by taking up housing space and through negative interactions with parents. If a child shares a space with other household members, s/he may have problems with interrupted sleep because of other members' different 
schedules, causing concentration difficulties during the day and further behavior disorders (Solari and Mare 2012). Tension between mothers and extended family members regarding the exchange of assistance may harm children's emotional development (Choi \& Marks, 2006; Cramer \& McDonald, 1996; Okun \& Keith, 1998; Taylor \& Roberts, 1995). In addition, extended family members may not possess enough material, human, and social capital to help (Menjívar 2000), or may absorb resources that would otherwise be used for the children in a household (Leach 2012). Elderly members, who are more likely to be disabled or ill, may take valuable resources from the children, such as money, time, attention, and space. The increased caregiving burden on parents may lead to decreased interactions with children, which could affect child behavioral adjustment and psychological health. However, empirical evidence to support this idea is lacking.

\section{Extended Family Household: Single-Parent vs. Married-Parent}

A substantial number of studies on the influence of extended family do not address the potentially different implications of co-resident extended kin by family structure. Much of the literature focuses on single parents and suggests that extended family members play a positive role. With co-resident extended kin, children in single-parent families show no difference in delinquency outcomes (Dornbusch et al., 1985; Zimmerman, Salem, \& Maton, 1995) or psychological well-being compared to those in married-parent families (S. G. Kellam, Ensminger, \& Turner, 1977; Sheppard G. Kellam, Adams, Brown, \& Ensminger, 1982). Married parents are generally less likely to live in poverty, and thus less likely to rely on kin networks for financial and social assistance compared to single parents (Cohen, 2002; Wiemers, 2014). Thus, children with married parents may not benefit from co-residing extended family members as much as do children with single parents. 


\section{Extended Family Living Arrangements across Immigrant Groups}

Parental immigrant status determines structural resources and behavioral characteristics (Glick \& White, 2004). Foreign-born parents, including unauthorized immigrants (Passel and Taylor 2010), are more likely to be married (Landale et al., 2011), and are more likely than native families to have extended relatives in the household due to material hardship, including limited access to housing (Hernandez, 2004; Yoshikawa 2011). Immigrant families are also overrepresented among the poor, and tend to live in crowded housing (Hernandez, 2004). Undocumented immigrants have even less schooling, lower incomes, and fewer financial holdings than documented immigrants, limiting their ability to attain desirable housing (Hall \& Greenman 2013).

Given that opportunities and resources differ by immigration status, the implications of extended kin may also differ across immigration groups. On one hand, some propose that extended kin in immigrant families provide children with greater health advantages, due to familism (Almeida, Molnar, Kawachi, \& Subramanian, 2009; Behnke et al., 2008; Harrison, Wilson, Pine, Chan, \& Buriel, 1990; Heard, 2007; Marsiglia, Parsai, \& Kulis, 2009; Uttal, 1999). Familism can be defined as a sense of duty, respect, solidarity, and interdependence towards an individual's family (Cardoso \& Thomson, 2010; Updegraff, McHale, Whiteman, Thayer, \& Delgado, 2005). The extent to which such values are emphasized varies for different cultural and social groups (Fuligni \& Pedersen, 2002). Because individuals who endorse familistic values tend to cooperate with family members (Behnke et al. 2008), immigrants are expected to receive greater benefits from their extended kin. It has been proposed that such supportive exchanges among extended kin give children of immigrants a health advantage (Heard, 2007; Zeiders et al., 2011). 
On the other hand, the structural disadvantages facing immigrants limit their family functioning. Low socioeconomic status (Hogan, Eggebeen, and Clogg 1993) and low levels of human capital (Hernandez, 2004, p. 23) restrict the extent and quality of immigrant social networks. For example, Menjívar (2000) found that Salvadoran immigrants did not successfully exchange social support under conditions of extreme poverty. Indeed, racial minority immigrant parents (Turney \& Kao, 2009) have smaller, less cohesive, and less diverse social networks than their US-born counterparts (Almeida, Kawachi, Molnar, \& Subramanian, 2009; Viruell-Fuentes et al., 2013). In addition, research on migration networks, in which new arrivals rely on previous arrivals for housing and settlement (Vallejo 2012), may indicate that the children of more established immigrants have to share resources with newer additional members (Leach 2012).

Recent research attends to the limiting effects of undocumented status on immigrants' support networks (Viruell-Fuentes \& Schulz, 2009). Yoshikawa (2011) assumes that undocumented parents would have less social support available in their social networks than documented or native parents, because extended adults in the households of undocumented parents tend to be also undocumented. Undocumented immigrants are reluctant or unable to access resources that require identification; therefore, their children are further disadvantaged. In addition, grandparents, who provide the most significant source of child care, are less likely to co-reside or live near undocumented families (Yoshikawa 2011: 22). Hence, children of undocumented parents are expected to receive less support from extended kin compared to children of documented immigrants.

Immigration status may alter the role of extended kin in single- versus married-parent families. Considering that parental involvement in a migration network determines the direction of exchanges (Menjívar 2000; Vallejo 2012), the exchange relationship in extended families with 
married parents will be even more asymmetric for immigrant families, in which the nuclear family provides resources to co-resident extended kin. It is unclear, though, whether this pattern will hold for both documented and undocumented immigrant families, given the structural differences between these two groups.

\section{HYPOTHESES}

This paper tests four hypotheses:

a) The co-residence of extended kin will be associated with lower child behavioral problems.

Numerous researchers have found a positive association between child development and the co-residence of extended kin. Although extended members may harm children's development by diverting resources and increasing family stress, previous empirical research has not supported this possibility.

b) The association between the co-residence of extended kin and children's behavioral problems will be conditional on parental marital status.

Compared to single-parent families, married-parent families are less likely to be poor, and thus less likely to rely on extended kin for support. For this reason, the co-residence of extended kin may not be as beneficial for married-parent families as it is for single-parent families.

c) The association between the co-residence of extended kin and children's behavioral problems will vary across immigrant groups by nativity and documentation status.

Despite the potentially stronger familism among immigrants, structural disadvantages (i.e., poverty) likely limit the extent and quality of support from extended kin. Undocumented status may further impair the support network functioning, reducing the potential benefits of extended kin support. 
d) The interactional association between the co-residence with extended kin and family structure on children's problem behaviors will vary across immigrant groups by nativity and documentation status.

Immigrants are often involved in migration networks, in which extended kin rely on the nuclear family. For immigrant extended families, the differential implications of co-resident extended kin in single- versus married-parent families may be amplified. However, this asymmetric exchange relationship may not hold for undocumented immigrants, due to their weaker social position.

\section{DATA AND METHOD}

Sample

The data come from the first wave of the Los Angeles Family and Neighborhood Survey (L.A. FANS). The first wave was fielded between April 2000 and January 2002. In Los Angeles in 2000, the population was 45 percent Latino, 31 percent white, 12 percent Asian and Pacific Islander, and 10 percent black; and 36 percent of the population was foreign-born (U.S. Census Bureau 2000). The L.A. FANS sample closely corresponds to this population distribution. Racial minority immigrants start their settlement as a numerical majority in Los Angeles, and this context will provide a valuable barometer of future children of immigrants' adjustment into the U.S. (Landale et al. 2015).

The L.A. FANS procured information from 2950 households with children (age 17 or younger). Families with children and families living in poor neighborhoods were oversampled, which we account for by using survey weights. In many sampled households, more than one respondent was interviewed. In households with children, a randomly selected child (RSC) was chosen to be included. If the randomly selected child had any siblings (SIB) in the household, 
one of his or her siblings was also randomly selected. Because some households contain more than one child, we account for clustering within households. A parent of the randomly selected child was selected as a respondent and designated as the primary caregiver; most were mothers, although fathers or grandparents could also be the primary caregiver. If the RSC's mother did not live in the household or was unable to answer questions about the child, the child's actual primary caregiver was selected as the primary caregiver respondent to provide information on the RSC and SIB. In each sampled household, one adult respondent was selected at random; this randomly selected adult and the primary caregiver respondent was the same person in some households.

The sample is limited to 1552 children and their siblings aged 3-11 in 1190 households whose primary caregiver completed an adult questionnaire, a parent questionnaire, and a primary caregiver questionnaire. About 99 percent of primary caregivers completed both a parent questionnaire and an adult questionnaire. Initially, there were 3041 children in 1911 households whose primary caregivers completed all three types of questionnaires. Among those, 1643 children were aged 3-11 (Behavior problems were assessed in children aged 3 years or older in the L.A. FANS, and primary school typically ends at age 11). One child of undocumented Asian immigrant parents was excluded because this child was distinct from the children of undocumented Latino parents who comprised the rest of the sample. Lastly, those with missing data on the measured variables were excluded ( 5.5 percent, $n=90)$. The excluded families were more likely to be immigrants, headed by single-parents, live with extended kin, have low income, have a depressed primary caregiver, and report more externalizing behaviors. (Tests using multiple imputation showed that these missing cases did not substantially change our 
results). The final sample includes 568 children of natives, 664 children of documented immigrants, and 320 children of undocumented immigrants.

\section{Measures}

\section{Dependent Variable}

The Behavior Problems Index was designed to assess children's behavior problems, including anxiety, depression, and aggression. This instrument has been used extensively in studies of mental health problems in children (Stevens and Volleberg 2008). Parents responded to the BPI questions using a three-point Likert scale that indicated how true each statement was of their child. The BPI consists of two subscales: internalizing and externalizing.

Internalizing behavior problems are defined as "an over-control of emotions" in the form of withdrawal, anxiety, and depression; feelings of worthlessness or inferiority; and dependency (Guttmannova, Szanyi, \& Cali, 2008, p. 2). The measure consists of 11 items assessing children's feeling sad, depressed, unhappy, or exhibiting withdrawn behaviors. Items are measured on a three-point Likert scale: 1 if the statement is often true, 2 if the statement is sometimes true, and 3 if the statement is not true. A reliability test indicates a Cronbach's alpha of .73 .

Externalizing behavior problems are characterized by "an under-control of emotions" in the form of delinquency, difficulties with interpersonal relationships, and displays of belligerence (Guttmannova et al., 2008, p. 1). The measure consists of 17 items assessing children's disobedient behaviors, or trouble getting along with teachers and other children. A reliability test indicates a Cronbach's alpha of .87. Higher scores on both indices indicate greater incidence of behavior problems. 
The measures of internalizing and externalizing behavior problem index scores are positively skewed. Heteroscedasticity and inflated standard errors of the estimates in regression analysis resulting from skewed variables can lead to reduced statistical power and larger confidence intervals (Berk, 1983). To reduce these problems, the behavior problem scores are logged. In order to make the descriptive statistics more interpretable, we logged them with the base of two, so that a one-unit increase in the dependent variable indicates a doubling of the behavior problem index score.

\section{Independent Variables}

The independent variable under investigation is the presence of extended kin $(0=$ no extended kin, 1= at least one present). Extended family households are defined as households that include non-nuclear family member(s) including grandparents, parents (in-law), siblings (inlaw), and grandchildren of the householder. Although 40 families ( 3 percent) in the sample had non-kin (e.g., friends) in their households, we do not define such households as extended family households because there are significant differences between kinship support and friendship support (Almeida, Subramanian, Kawachi, \& Molnar, 2011; Xue, 2015). In addition, our preliminary analysis uncovered no confounding effects of non-kin in the association between extended kin and the child outcomes studied; thus, we excluded the variable from the final models.

\section{Moderators}

Family Structure The family support system was measured using marital status of the primary caregiver, $0=$ married, $1=$ not married (divorced, separated, widowed, or never married). There was no statistically significant difference in child outcomes between previously married 
(divorced, separated, and widowed) and never-married families. Thus, we collapsed the nonmarried categories into one.

Primary Caregiver's immigrant status (nativity and documented status). Using questions about the primary caregiver's place of birth, we identified immigrant status. Next, their documented status was determined by a series of questions (Landale et al. 2015). First, the respondents were asked whether they were naturalized citizens. If not, they were asked whether they had a green card, or documented permanent residence. Immigrants who were neither citizens nor permanent residents were asked whether they had been granted asylum or refugee status. Finally, the respondents who did not have any of those statuses were asked whether they had a valid visa. Immigrants who were not authorized - neither naturalized citizens, permanent residents, nor documented — were coded as undocumented. The variable is categorical ( $0=\mathrm{US}-$ born/native, 1 =foreign-born/documented immigrant, 2=foreign-born/undocumented immigrant).

Children's nativity was not separately controlled. More than 90 percent of the children of documented immigrants, and more than 75 percent children of undocumented immigrants, were born in the United States (the $2^{\text {nd }}$ generation).

\section{Control variables}

Primary Caregiver's depressive symptoms. A short form (CIDI-SF) questionnaire covers major depressive episodes (MD) of the primary caregivers. The CIDI-SF questions for MD reports the respondents' feeling sad, blue, or depressed for two weeks or more in the past 12 months (dysphoric); if they did, whether they had lost interest in most things like hobbies, work, or activities that usually give pleasure (anhedonic). The MD reports provide a probability between 0 and 1 that the person is suffering from major depression. Following Landale et al. (2015), we coded respondents as "depressed" if their probability of depression was greater than 
0.5 and "not depressed" if the probability was less than 0.5 . We controlled for this variable because of the correlation between parental report of behavioral problems and parental depression.

Primary Caregiver's race/ethnicity. Race/ethnicity of the primary caregiver was determined by self-report. The four racial or ethnic groups that were used in these analyses are white, black, Latino, and Asian.

Primary Caregiver's educational attainment. This variable is used as a dichotomous measure: $0=$ less than high school; $1=$ high school and greater. The majority of primary caregivers in the L.A. FANS did not have a high school diploma; thus, high school completion was used as the cut-off.

Family income. The incomes from head of household, spouse/partner of head, and children were reported for the calendar year prior to the interview year. Except for family income, other variables were measured at the time of survey. The sum of that income was (natural) logged for the analysis.

Child sex and age. The variable for child's sex is dichotomous ( $0=$ female, $1=$ male), and age is continuous.

\section{DESCRIPTIVE RESULTS}

Table 1 presents the sample characteristics. We performed the significance tests using bivariate regression analyses (OLS or logistic) for all the variables on parent's nativity and documentation status. Compared with children of US-born parents, children of documented immigrant parents in this sample show significantly higher levels of internalizing behaviors ( 0.99 vs. 1.22). Relative to those of documented immigrants, children of undocumented immigrants report significantly higher internalizing behaviors (1.22 vs. 1.95). Regarding externalizing behaviors, on the other 
hand, children of documented immigrants have lower levels of behavioral problems than children of natives (1.96 vs. 2.27). However, when we compare the sample by documentation status of foreign-born parents, children of undocumented immigrants show significantly higher levels of externalizing behaviors (1.96 vs. 2.51).

There are significant differences in family and household structure across the immigrant status groups. Children of undocumented immigrants are the least likely to live in two-parent nuclear families, and are more likely to be with single parents than are documented immigrants (45 percent vs. 26 percent). Undocumented immigrants are more likely to live with extended kin (36 percent) compared to those of US-born parents ( 22 percent) and documented immigrants ( 25 percent). When specifying extended family households by family structure, both documented and undocumented immigrants are more likely to live in married-parent extended family households; those who are documented are less likely to live in single-parent extended families than other groups.

The descriptive results for covariates show that children of immigrants, especially those of undocumented immigrants, are living in relatively disadvantaged conditions. Over 80 percent of children of undocumented immigrants, and about half with documented immigrant primary caregivers, have parents who did not complete high school, compared to 12 percent of their USborn counterparts. The difference in family incomes is striking. Undocumented immigrant families have only $\$ 10,829\left(=\mathrm{e}^{9.29}\right)$ annual income on average, which is less than one-third of the figure for native families and less than half of the figure for documented immigrants.

Documented immigrant families have $\$ 23,623\left(=\mathrm{e}^{10.07}\right)$ annual income on average, which is about $\$ 19,400$ lower than native families $\left(\$ 43,045\right.$, or $\left.\mathrm{e}^{10.67}\right)$.

[Table1 about here] 


\section{ANALYTICAL RESULTS}

Table 2 presents the results of ordinary least squares regression analyses for the full sample, and for each immigrant group: US-born, documented immigrant, and undocumented immigrant families. First, we look at the results for all groups. In Model 1, the presence of extended kin is associated with 19 percent higher (worse) internalizing behaviors $\left[=100 *\left(2^{0.262}-1\right]\right.$, compared with those children without extended kin in the household, net of the array of covariates $(p<.01)$. Similarly, the co-residence of extended kin is associated with a higher incidence of externalizing behaviors, but the association is not statistically significant. In Model 2, the presence of extended kin negatively interacts with a single-parent family structure for both internalizing and externalizing behaviors, indicating that single-parent extended families have a lower incidence of problems than do married-parent extended families. The differences are significant at the marginal level $(p<.10)$.

For children of US-born parents, in Model 1, the presence of extended kin is associated with more internalizing behaviors among children, compared to households without extended kin, at a statistically marginal level $(p<.10)$. For externalizing behaviors, extended kin are associated with greater incidence of problems among children, but the association is not statistically significant. In Model 2, for child internalizing behaviors, the presence of extended kin has almost no interactional association with single-parent families, indicating that the role of extended kin does not differ between single- and two-parent families. For children's externalizing behaviors, the presence of extended kin negatively interacts with single-parent family structure, indicating that single-parent extended families are associated with fewer problems than married-parent extended families, but the relationship is statistically not significant. 
[Table 2 about here]

Next, we look at the results for children of documented immigrants. In Model 1, the coresidence of extended kin is associated with about 19 percent higher (worse) internalizing behavior $(p<.05)$. However, as Model 2 shows, the positive association between the presence of extended kin and child outcome mostly comes from married-parent families. Compared with those in nuclear families, children in married-parent extended family households report 47.8 percent higher internalizing behaviors $(p<.001)$, whereas children in single-parent extended family households show only about 13 percent higher internalizing behaviors $\left[=100 *\left\{2^{(0.727+0.564-1.110)}-1\right\}\right]$. For externalizing behaviors, in Model 1, co-resident extended kin appear to have no significant influence on children. However, as Model 2 shows, family structure moderates the extended kin association. Compared with children in nuclear families, children in married-parent extended family households show 26 percent higher externalizing behavior, and those in single-parent extended family households show only 10 percent higher externalizing behavior $\left.\left[=100 *\left\{2^{(0.313+0.520-.684)}-1\right\}\right\}\right]$. The pattern is similar to the results for internalizing behaviors.

Lastly, we look at the results for children of undocumented immigrants. In Model 1, the presence of extended kin has no statistically significant association with either internalizing or externalizing behaviors. Model 2 shows that the co-residence of extended kin has a positive interactional association with family structure for child internalizing behaviors, but the relationship is not statistically significant. For externalizing behaviors, the interaction between extended kin and family structure is negative, but the interaction term does not reach statistical significance. 
In an analysis not shown, we tested whether the coefficients across three separate models are significantly different. Although the coefficient of extended kin does not differ across the immigrant groups, the interaction term does differ for internalizing behaviors. The coefficient of the interaction term between extended kin and family structure is significantly different between documented immigrant families and native families $(\mathrm{p}<.05)$, as well as undocumented immigrant families $(\mathrm{p}<.01)$. This pattern is consistent with the result of testing three-way interactions among extended kin, family structure, and immigration status for all respondents (available upon request).

In an additional set of models (not shown), we included a control for the total number of household members, which is highly correlated with the presence of extended kin, reducing by about 30 percent the coefficient of extended kin on children's internalizing behavior problems, and 50 percent on externalizing behavior problems. Nevertheless, the interaction terms between the presence of extended kin and family structure changed very little. This suggests that although the influence of co-residence with extended kin is partially attributable to crowded housing conditions, this is only the case among married-parent families.

\section{DISCUSSION \& CONCLUSION}

We examined how co-resident extended kin are associated with child behavior, how this association is moderated by family structure, and how the patterns vary across parental immigration and documentation status. We found that extended kin were significantly associated with higher (worse) internalizing behaviors, but the positive association was only significant among married-parent families. Research by Jayakody et al. (1993) implied that when marriedcouple families host extended kin, they were less likely to be receiving assistance and more likely to be providing it - which might work to the detriment of their children. Consistent with 
the more reciprocal relationship with extended kin in single-parent families, children in singleparent extended family households showed no significant difference from those in nuclear families, which was also the case in previous findings (Dornbusch et al. 1985; Zimmerman, Salem, and Maton, 1995; Dunifon and Kowaleski-Jones 2007).

This pattern emerged even more strongly among children of documented immigrants, compared to those of natives and those of unauthorized immigrants. We suspect this is because more established families — such as those who are married and documented — tend to support poorer extended kin and others who are less able to provide benefits to their host families (Leach 2012; Vallejo 2012). Perhaps, the extended kin are new arrivals who are more likely to be in a position to receive support than to give it (Brown, 2007; Menjívar, 2000). One potential mediator of extended kin effects is household crowding, which could not be disentangled from family structure effects in these data; this question deserves additional attention.

While extended kin were significantly associated with higher (worse) internalizing behaviors, they were not significantly associated with externalizing behaviors. It may be that children are over-controlling their emotions and behaviors in extended families, rather than under-controlling them. Extended kin may contribute to over-controlling regulations and stimulate negative emotions (Eisenberg et al. 2000). Examples of negative stimulation could be tension between parents and extended members, increased caregiving burden for parents, or child stress from sharing money, time, attention, and space with additional family members. However, the precise mechanisms underlying these different patterns between extended kin and internalizing vs. externalizing behaviors are not clear. Identifying the different mechanisms requires further research. 
Overall, these findings contrast with prior studies that have suggested extended family networks are protective for children (Dunifon \& Kowaleski 2007; Foster \& Kalil, 2007). This is probably due to three major differences from previous studies. First, many prior studies on extended families have focused on single mother families (Castiglia 1999; Deleire and Kalil 2002; Dunifon \& Kowaleski 2007). In this study, we attend not only to single-parent families but also to married-parent families. As our descriptive results show, children of immigrant families are more likely to live with extended kin, in the presence of married parents. Thus, incorporating this type of extended arrangement is essential, and this inclusion may explain why we found a positive association between the presence of extended kin in the household and child behavioral problems. Second, the sample consists primarily of families living in poorer Los Angeles areas. Family networks may not function as effectively under conditions of poverty (Hogan et al. 1993; Menjívar 2000). Third, the definition of extended family network is limited to co-resident extended kin in this study. Interactions beyond the household which might have been protective (such as from relatives living nearby) are thus not measured.

The results point to the need to modify extant theories on extended family support. Current theory views the extended family as a "problem-solving" system (Castiglia, 1999; Harrison, et al. 1990, p. 351; Wilson, 1989). Particularly, extended kin adults are assumed to be assets in immigrant families (Portes \& Rumbaut, 2001). The theory should be revised to consider the familial and structural context of the co-residence with extended kin. The direction and quality of exchange relationships within extended family households vary by family structure and across parental nativity and documentation status. Failure to distinguish extended families by family structure and immigration status masks important differences in the family dynamics within extended families. 
The current study is not free from limitations. Information about extended family members' immigration status was unavailable. Ideally, future research should take into account the ways in which extended members' immigrant status may influence their family roles. This research will help identify whether extended family members are more burdensome than beneficial to their host family when they are newly arriving immigrants. In addition, the relatively small sample size for each sub-group, and the stratifying analyses on the sub-samples, make it difficult to be certain that the patterns are truly different across immigrant status. Future research should investigate whether the null results of the co-residence with extended kin for undocumented immigrant families can be replicated with other data. However, the L.A. FANS is one of the few representative data sources with detailed questions on the documentation status of parents.

Although our findings need to be confirmed with additional data, this research provides implications for policies. We reveal that co-residence with extended kin is significantly associated with higher internalizing behaviors among children, but the association holds only for married-parent families. Those families are more likely to live in crowded housing than are single-parent families. The results underscore the potential benefits of providing housing support, with an eye toward the demands on married-parent families who may be sharing their house with extended kin. The comparison across parental immigrant status shows that the differential implications of co-residence with extended kin by family structure are the clearest among documented immigrant families. Although we cannot identify whether the co-resident extended kin are newly arriving immigrants, numerous researchers have documented previous arrivals offering housing to newcomers (Brown 2007; Menjívar 2000; Vallejo 2012). If the 
burden of helping new arrivals falls on documented immigrants, due to the lack of an integration policy for immigrants, it may be time to establish one for the sake of future citizens.

\section{REFERENCE}

Almeida, J., Kawachi, I., Molnar, B. E., \& Subramanian, S. V. (2009). A Multilevel Analysis of Social Ties and Social Cohesion among Latinos and Their Neighborhoods: Results from Chicago. Journal of Urban Health, 86(5), 745-759.

Almeida, J., Molnar, B. E., Kawachi, I., \& Subramanian, S. V. (2009). Ethnicity and nativity status as determinants of perceived social support: Testing the concept of familism. Social Science \& Medicine, 68(10), 1852-1858.

Almeida, J., Subramanian, S. V., Kawachi, I., \& Molnar, B. E. (2011). Is blood thicker than water? Social support, depression and the modifying role of ethnicity/nativity status. Journal of Epidemiology and Community Health, 65(1), 51-56.

Barrett, A. E., \& Turner, R. J. (2005). Family Structure and Mental Health: The Mediating Effects of Socioeconomic Status, Family Process, and Social Stress. Journal of Health and Social Behavior, 46(2), 156-169.

Bean, F. D., Brown, S. K., \& Bachmeier, J. D. (2015). Parent without papers: the progress and pitfalls of Mexican-American integration. New York: Russell Sage Foundation.

Behnke, A. O., MacDermid, S. M., Coltrane, S. L., Parke, R. D., Duffy, S., \& Widaman, K. F. (2008). Family Cohesion in the Lives of Mexican American and European American Parents. Journal of Marriage and Family, 70(4), 1045-1059.

Berk, R. A. (1983). Applications of the general linear model to survey data. In Handbook of survey research (pp. 495-546). Academic Press New York.

Bornstein, M. H. (2002). Handbook of parenting. Mahwah, N.J.: Erlbaum. 
Brown, S. K. (2007). Delayed Spatial Assimilation: Multigenerational Incorporation of the Mexican-Origin Population in Los Angeles. City \& Community, 6(3), 193-209.

Cardoso, J. B., \& Thomson, S. (2010). Common Themes of Resilience among Latino Immigrant Families: A Systematic Review of the Literature. Families in Society: The Journal of Contemporary Social Services, 91(3), 257-265.

Carlson, M. J., \& Corcoran, M. E. (2001). Family structure and children's behavioral and cognitive outcomes. Journal of Marriage and Family, 63(3), 779-792.

Castiglia, P. T. (1999). Extended families: Social support systems for children. Journal of Pediatric Health Care, 13(3), 139-141.

Cohen, P. N. (2002). Extended households at work: Living arrangements and inequality in single mothers' employment. In Sociological Forum (Vol. 17, pp. 445-463). Springer.

DeLeire, T., \& Kalil, A. (2002). Good things come in threes: Single-parent multigenerational family structure and adolescent adjustment. Demography, 39(2), 393-413.

Dornbusch, S. M., Carlsmith, J. M., Bushwall, S. J., Ritter, P. L., Leiderman, H., Hastorf, A. H., \& Gross, R. T. (1985). Single Parents, Extended Households, and the Control of Adolescents. Child Development, 56(2), 326.

Dressler, W. W. (1985). Extended Family Relationships, Social Support, and Mental Health in a Southern Black Community. Journal of Health and Social Behavior, 26(1), 39-48.

Edin, K., \& Lein, L. (1997). Making ends meet: how single mothers survive welfare and lowwage work. New York: Russell Sage Foundation.

Eisenberg, N., Fabes, R. A., Guthrie, I. K., \& Reiser, M. (2000). Dispositional emotionality and regulation: Their role in predicting quality of social functioning. Journal of Personality and Social Psychology, 78(1), 136-157. 
Fanti, K. A., \& Henrich, C. C. (2010). Trajectories of pure and co-occurring internalizing and externalizing problems from age 2 to age 12: Findings from the National Institute of Child Health and Human Development Study of Early Child Care. Developmental Psychology, 46(5), 1159-1175.

Foster, E. M., \& Kalil, A. (2007). Living arrangements and Children's development in LowIncome White, Black, and Latino families. Child Development, 78(6), 1657-1674.

Fuligni, A. J., \& Pedersen, S. (2002). Family Obligation and the Transition to Young Adulthood. Developmental Psychology, 38(5), 856-868.

García Coll, C., \& Marks, A. K. (2009). Immigrant stories: Ethnicity and academics in middle childhood. Oxford University Press.

García Coll, C., Crnic, K., Lamberty, G., Wasik, B. H., Jenkins, R., Garcia, H. V., \& McAdoo, H. P. (1996). An integrative model for the study of developmental competencies in minority children. Child Development, 67(5), 1891-1914.

Glick, J. E., \& White, M. J. (2004). Post-secondary school participation of immigrant and native youth: the role of familial resources and educational expectations. Social Science Research, 33(2), 272-299.

Gross, J. J. (2007). Handbook of emotion regulation. New York: Guilford Press.

Guttmannova, K., Szanyi, J. M., \& Cali, P. W. (2008). Internalizing and Externalizing Behavior Problem Scores: Cross-Ethnic and Longitudinal Measurement Invariance of the Behavior Problem Index. Educational and Psychological Measurement, 68(4), 676-694.

Hall, M., \& Greenman, E. (2013). Housing and neighborhood quality among undocumented Mexican and Central American immigrants. Social Science Research, 42(6), 1712-1725. 
Harrison, A. O., Wilson, M. N., Pine, C. J., Chan, S. Q., \& Buriel, R. (1990). Family ecologies of ethnic minority children. Child Development, 61(2), 347-362.

Heard, H. E. (2007). The Family Structure Trajectory and Adolescent School Performance: Differential Effects by Race and Ethnicity. Journal of Family Issues, 28(3), 319-354. Hernandez, D. J. (2004). Demographic Change and the Life Circumstances of Immigrant Families. The Future of Children, 14(2), 17-47.

Hofferth, S. L., Boisjoly, J., \& Duncan, G. J. (1998). Parents’ extrafamilial resources and children's school attainment. Sociology of Education, 246-268.

Hogan, D. P., Eggebeen, D. J., \& Clogg, C. C. (1993). The Structure of Intergenerational Exchanges in American Families. American Journal of Sociology, 98(6), 1428-1458.

Jacobsen, L. A., Mather, M., \& Dupuis, G. (2012). Household change in the United States (Vol. 67). Population Reference Bureau Washington, DC.

Jayakody, R., Chatters, L. M., \& Taylor, R. J. (1993). Family Support to Single and Married African American Mothers: The Provision of Financial, Emotional, and Child Care Assistance. Journal of Marriage and Family, 55(2), 261-276.

Kellam, S. G., Adams, R. G., Brown, C. H., \& Ensminger, M. E. (1982). The Long-Term Evolution of the Family Structure of Teenage and Older Mothers. Journal of Marriage and Family, 44(3), 539-554.

Kellam, S. G., Ensminger, M. E., \& Turner, R. J. (1977). Family structure and the mental health of children. Concurrent and longitudinal community-wide studies. Archives of General Psychiatry, 34(9), 1012-1022. 
Landale, N. S., Hardie, J. H., Oropesa, R. S., \& Hillemeier, M. M. (2015). Behavioral Functioning among Mexican-origin Children Does Parental Legal Status Matter? Journal of Health and Social Behavior, 56(1), 2-18.

Landale, N. S., Thomas, K. J. ., \& Van Hook, J. (2011). The Living Arrangements of Children of Immigrants. Future of Children, 21, 43-70.

Leach, M. a. (2012). A Burden of Support? Household Structure and Economic Resources Among Mexican Immigrant Families. Journal of Family Issues, 35, 28-53.

Marsiglia, F. F., Parsai, M., \& Kulis, S. (2009). Effects of Familism and Family Cohesion on Problem Behaviors among Adolescents in Mexican Immigrant Families in the Southwest U.S. Journal of Ethnic \& Cultural Diversity in Social Work, 18(3), 203-220.

McLanahan, S., \& Sandefur, G. D. (1994). Growing up with a single parent: what hurts, what helps. Cambridge, Mass.: Harvard University Press.

McLeod, J. D., \& Kaiser, K. (2004). Childhood Emotional and Behavioral Problems and Educational Attainment. American Sociological Review, 69(5), 636-658.

Menjívar, C. (2000). Fragmented ties : Salvadoran immigrant networks in America. Berkeley: University of California Press.

Passel, J. S., \& Taylor, P. (2010). Unauthorized Immigrants and Their U.S.-Born Children. Washington, DC: Pew Hispanic Center.

Portes, A., \& Rumbaut, R. G. (2001). Legacies : the story of the immigrant second generation. Berkeley; New York: University of California Press ; Russell Sage Foundation.

Sarkisian, N. (2006). "Doing family ambivalence": Nuclear and extended families in single mothers' lives. Journal of Marriage and Family, 68(4), 804-811. 
Solari, C. D., \& Mare, R. D. (2012). Housing crowding effects on children's wellbeing. Social Science Research, 41(2), 464-476.

Suárez-Orozco, C., Teranishi, R. T., Suárez-Orozco, M. M., \& Yoshikawa, H. (2011). Growing up in the shadows: The developmental implications of unauthorized status. Harvard Educational Review, 81(3), 438-472.

Tienda, M., \& Glass, J. (1985). Household Structure and Labor Force Participation of Black, Hispanic, and White Mothers. Demography, 22(3), 381.

Turney, K., \& Kao, G. (2009). Assessing the Private Safety Net: Social Support among Minority Immigrant Parents. Sociological Quarterly, 50(4), 666-692.

Updegraff, K. A., McHale, S. M., Whiteman, S. D., Thayer, S. M., \& Delgado, M. Y. (2005). Adolescent sibling relationships in Mexican American families: Exploring the role of familism. Journal of Family Psychology, 19(4), 512-522.

U.S. Census Bureau. (2000). Census 2000. Summary File $1 \&$ Summary File 4. Washington, DC Uttal, L. (1999). Using Kin for Child Care: Embedment in the Socioeconomic Networks of Extended Families. Journal of Marriage and Family, 61(4), 845-857.

Vallejo, J. A. (2012). Barrios to burbs the making of the Mexican-American middle class (Vols. 1-1 online resource (xiv, 231 pages)). Stanford, Calif.: Stanford University Press.

Van Hook, J., \& Glick, J. E. (2007). Immigration and living arrangements: moving beyond economic need versus acculturation. Demography, 44(2), 225-249.

Viruell-Fuentes, E. A., Morenoff JD, Williams DR, \& House JS. (2013). Contextualizing nativity status, Latino social ties, and ethnic enclaves: an examination of the "immigrant social ties hypothesis". Ethnicity \& Health, 18(6), 586-609. 
Viruell-Fuentes, E. A., \& Schulz, A. J. (2009). Toward a Dynamic Conceptualization of Social Ties and Context: Implications for Understanding Immigrant and Latino Health. American Journal of Public Health, 99(12), 2167-2175.

Wen, M. (2008). Family Structure and Children's Health and Behavior Data From the 1999 National Survey of America's Families. Journal of Family Issues, 29(11), 1492-1519.

Wiemers, E. E. (2014). The Effect of Unemployment on Household Composition and Doubling Up. Demography, 51(6), 2155-2178.

Wilson, M. N. (1989). Child development in the context of the Black extended family. American Psychologist, 44(2), 380.

Xue, M. (2015). Social support from friends and family in a Tibetan village. Personal Relationships, 22(1), 30-44.

Yoshikawa, H. (2011). Immigrants raising citizens: undocumented parents and their young children. New York: Russell Sage Foundation.

Zeiders, K. H., Roosa, M. W., \& Tein, J.-Y. (2011). Family Structure and Family Processes in Mexican-American Families. Family Process, 50(1), 77-91.

Zimmerman, M. A., Salem, D. A., \& Maton, K. I. (1995). Family Structure and Psychosocial Correlates among Urban African-American Adolescent Males. Child Development, 66(6), 1598-1613. 


\section{Table 1. Weighted Descriptive Statistics of Sample by Parental Nativity and Documentation}

Status

\begin{tabular}{|c|c|c|c|c|c|c|c|c|}
\hline & All & S.E. & US-born $^{\mathrm{a}}$ & S.E. & Documented $^{\mathrm{b}}$ & S.E. & Undocumented & S.E. \\
\hline Internalizing BPI $\left(\log _{2}\right)$ & 1.23 & $(0.04)$ & 0.99 & $(0.07)$ & $1.22^{\mathrm{a}}$ & $(0.07)$ & $1.95^{\mathrm{a}, \mathrm{b}}$ & $(0.08)$ \\
\hline Externalizing BPI $\left(\log _{2}\right)$ & 2.18 & $(0.05)$ & 2.27 & $(0.08)$ & $1.96^{\mathrm{a}, \mathrm{b}}$ & $(0.08)$ & $2.51^{\mathrm{b}}$ & $(0.10)$ \\
\hline \multicolumn{9}{|l|}{ Child characteristics } \\
\hline $\begin{array}{l}\text { Child sex } \\
\text { (ref. girl) }\end{array}$ & 0.50 & $(0.02)$ & 0.49 & $(0.03)$ & 0.51 & $(0.03)$ & 0.48 & $(0.04)$ \\
\hline Child age & 7.02 & $(0.09)$ & 7.06 & $(0.14)$ & 7.04 & $(0.13)$ & 6.84 & $(0.17)$ \\
\hline \multicolumn{9}{|c|}{ Primary caregiver characteristics } \\
\hline US-born parents & 0.44 & $(0.02)$ & & & & & & \\
\hline Immigrant & 0.56 & $(0.02)$ & & & & & & \\
\hline Documented immigrant & 0.41 & $(0.02)$ & & & 1.00 & & 0.00 & \\
\hline Undocumented & 0.15 & $(0.01)$ & & & 0.00 & & 1.00 & \\
\hline White & 0.22 & $(0.02)$ & 0.42 & $(0.03)$ & $0.09^{\mathrm{a}}$ & $(0.02)$ & 0.00 & \\
\hline Latino & 0.56 & $(0.02)$ & 0.28 & $(0.03)$ & $0.70^{a}$ & $(0.03)$ & 1.00 & \\
\hline Black & 0.11 & $(0.01)$ & 0.23 & $(0.03)$ & $0.02^{a}$ & $(0.01)$ & 0.00 & \\
\hline Asian & 0.11 & $(0.01)$ & 0.07 & $(0.02)$ & $0.19^{\mathrm{a}}$ & $(0.02)$ & 0.00 & $(0.01)$ \\
\hline Family income(ln) & 10.22 & $(0.05)$ & 10.67 & $(0.06)$ & $10.07^{\mathrm{a}}$ & $(0.09)$ & $9.29^{\mathrm{a}, \mathrm{b}}$ & $(0.17)$ \\
\hline PCG depression & 0.12 & $(0.01)$ & 0.13 & $(0.02)$ & 0.12 & $(0.02)$ & 0.10 & $(0.02)$ \\
\hline $\begin{array}{l}\text { PCG education. } \\
\text { (ref. }<\text { High) }\end{array}$ & 0.63 & $(0.02)$ & 0.88 & $(0.02)$ & $0.53^{\mathrm{a}}$ & $(0.03)$ & $0.18^{a, b}$ & $(0.03)$ \\
\hline \multicolumn{9}{|c|}{ Family household structure } \\
\hline Single parenthood & 0.35 & $(0.02)$ & 0.39 & $(0.03)$ & $0.26^{\mathrm{a}}$ & $(0.03)$ & $0.45^{b}$ & $(0.05)$ \\
\hline Extended $\mathrm{HH}$ & 0.25 & $(0.02)$ & 0.22 & $(0.03)$ & 0.25 & $(0.03)$ & $0.36^{\mathrm{a}, \mathrm{b}}$ & $(0.05)$ \\
\hline Two parent, nuclear & 0.51 & $(0.02)$ & 0.52 & $(0.03)$ & 0.56 & $(0.03)$ & $0.34^{\mathrm{a}, \mathrm{b}}$ & $(0.04)$ \\
\hline Two parent, extend & 0.14 & $(0.01)$ & 0.08 & $(0.02)$ & $0.18^{a}$ & $(0.02)$ & $0.21^{\mathrm{a}}$ & $(0.04)$ \\
\hline Single parent, nuclear & 0.24 & $(0.02)$ & 0.26 & $(0.03)$ & 0.19 & $(0.03)$ & 0.29 & $(0.04)$ \\
\hline Single parent, extend & 0.11 & $(0.01)$ & 0.13 & $(0.02)$ & $0.07^{\mathrm{a}}$ & $(0.01)$ & $0.16^{b}$ & $(0.03)$ \\
\hline Unweighted N & 1552 & & 568 & & 664 & & 320 & \\
\hline
\end{tabular}

Note: ${ }^{\text {a: }}$ Significantly different from children of US-born parents. ${ }^{\text {b: }}$ Significantly different from children of documented immigrant parents 
Table 2. Results of OLS Regression on Behavioral Problems for All and across Immigrant Groups

\begin{tabular}{|c|c|c|c|c|c|c|c|c|c|c|c|c|c|c|c|c|}
\hline & \multicolumn{4}{|c|}{ All } & \multicolumn{4}{|c|}{ US-born parents } & \multicolumn{4}{|c|}{ Documented immigrants } & \multicolumn{4}{|c|}{ Undocumented immigrants } \\
\hline & \multicolumn{2}{|c|}{$\begin{array}{c}\text { Internalizing } \\
\text { BPI }\end{array}$} & \multicolumn{2}{|c|}{$\begin{array}{c}\text { Externalizing } \\
\text { BPI }\end{array}$} & \multicolumn{2}{|c|}{$\begin{array}{c}\text { Internalizing } \\
\text { BPI }\end{array}$} & \multicolumn{2}{|c|}{$\begin{array}{c}\text { Externalizing } \\
\text { BPI }\end{array}$} & \multicolumn{2}{|c|}{$\begin{array}{c}\text { Internalizing } \\
\text { BPI }\end{array}$} & \multicolumn{2}{|c|}{$\begin{array}{c}\text { Externalizing } \\
\text { BPI }\end{array}$} & \multicolumn{2}{|c|}{$\begin{array}{c}\text { Internalizing } \\
\text { BPI }\end{array}$} & \multicolumn{2}{|c|}{$\begin{array}{c}\text { Externalizing } \\
\text { BPI }\end{array}$} \\
\hline & Model1 & Model2 & Model1 & Model2 & Model1 & Model2 & Model1 & Model2 & Model1 & Model2 & Model1 & Model2 & Model1 & Model2 & Model1 & Model2 \\
\hline Child sex (ref. girl) & .051 & .052 & $.219^{*}$ & $.220^{*}$ & .043 & .042 & 107 & .108 & .148 & .146 & $.338^{* *}$ & $.337^{* *}$ & -.146 & -.153 & .195 & .205 \\
\hline S.E. & $(.071)$ & $(.070)$ & $(.088)$ & $(.088)$ & $(.115)$ & $(.115)$ & $(.147)$ & $(.147)$ & $(.102)$ & $(.099)$ & $(.124)$ & $(.123)$ & $(.143)$ & $(.146)$ & $(.177)$ & $(.176)$ \\
\hline \multirow[t]{2}{*}{ Child age } & $-.025 \dagger$ & $-.026 \dagger$ & $-.053 \dagger$ & $-.054^{* *}$ & $-.043 \dagger$ & $-.043 \dagger$ & -.043 & -.043 & -.027 & -.027 & $-.075^{* * *}$ & $-.076^{* * *}$ & .015 & .014 & -.038 & -.037 \\
\hline & $(.014)$ & $(.014)$ & $(.017)$ & $(.017)$ & $(.023)$ & $(.023)$ & $(.029)$ & $(.029)$ & $(.020)$ & $(.019)$ & $(.023)$ & $(.023)$ & $(.028)$ & $(.028)$ & $(.031)$ & $(.031)$ \\
\hline \multirow{4}{*}{$\begin{array}{l}\text { Documented } \\
\text { (ref. US-born) } \\
\text { Undocumented }\end{array}$} & .069 & .045 & $-.352^{* * *}$ & $-.381^{* * *}$ & & & & & & & & & & & & \\
\hline & $(.107)$ & $(.106)$ & $(.129)$ & (.129) & & & & & & & & & & & & \\
\hline & $.584^{* * *}$ & $.554^{* * *}$ & .054 & .017 & & & & & & & & & & & & \\
\hline & $(.132)$ & $(.131)$ & $(.162)$ & $(.163)$ & & & & & & & & & & & & \\
\hline \multirow[t]{2}{*}{ Family income $(\ln )$} & -.018 & -.017 & .004 & .006 & -.017 & -.019 & -.038 & -.036 & -.025 & -.022 & $.055 \dagger$ & $.057 \dagger$ & -.010 & -.010 & $-.099^{* *}$ & $-.099^{* *}$ \\
\hline & $(.018)$ & $(.018)$ & $(.028)$ & $(.027)$ & $(.054)$ & $(.054)$ & $(.068)$ & $(.068)$ & $(.024)$ & $(.021)$ & $(.033)$ & $(.032)$ & $(.038)$ & $(.040)$ & $(.036)$ & $(.034)$ \\
\hline \multirow[t]{2}{*}{ PCG depression } & $.810^{* * *}$ & $.811^{* * * *}$ & $.796^{* * *}$ & $.797^{* * *}$ & $.852^{* * * *}$ & $.851^{* * *}$ & $.824^{* * * *}$ & $.825^{* * * *}$ & $.834^{* * *}$ & $.836^{* * *}$ & $.839^{* * *}$ & $.840^{* * *}$ & $.427^{*}$ & $.428^{*}$ & $.493^{*}$ & $.491^{*}$ \\
\hline & (.109) & (.109) & $(.111)$ & $(.111)$ & (.183) & $(.182)$ & $(.173)$ & $(.174)$ & $(.144)$ & $(.135)$ & $(.172)$ & $(.168)$ & $(.198)$ & $(.192)$ & $(.206)$ & $(.210)$ \\
\hline \multirow{2}{*}{$\begin{array}{l}\text { PCG education } \\
\text { (ref. }<\text { High) }\end{array}$} & $-.283^{* *}$ & $-.272^{* *}$ & -.030 & -.017 & $-.484^{*}$ & $-.490^{*}$ & -.358 & -.347 & .063 & -.046 & $.382^{*}$ & $.393^{* *}$ & $-.352^{*}$ & $-.356^{*}$ & -.335 & -.330 \\
\hline & $(.100)$ & $(.101)$ & $(.122)$ & $(.122)$ & $(.210)$ & $(.214)$ & $(.234)$ & $(.237)$ & (.137) & $(.127)$ & $(.165)$ & $(.160)$ & (.167) & $(.170)$ & $(.229)$ & $(.236)$ \\
\hline \multirow[t]{2}{*}{ Latino } & $.232^{*}$ & $.254^{*}$ & $.228 \dagger$ & $.254 \dagger$ & .046 & .040 & -.062 & -.050 & $.587^{* * *}$ & $.608^{* * * *}$ & $.971^{* * *}$ & $.984^{* * *}$ & & & & \\
\hline & $(.110)$ & $(.111)$ & (.137) & $(.136)$ & $(.145)$ & $(.145)$ & $(.171)$ & $(.171)$ & $(.165)$ & $(.157)$ & $(.223)$ & $(.220)$ & & & & \\
\hline \multirow[t]{2}{*}{ Black } & .132 & .105 & .105 & .072 & .197 & .205 & .085 & .068 & .092 & -.097 & .273 & .156 & & & & \\
\hline & (.193) & (.195) & $(.233)$ & $(.235)$ & $(.214)$ & $(.216)$ & $(.260)$ & $(.263)$ & $(.358)$ & $(.363)$ & $(.451)$ & $(.456)$ & & & & \\
\hline \multirow[t]{2}{*}{ Asian } & .038 & .043 & -.169 & -.163 & .258 & .259 & -.265 & -.267 & .214 & .189 & .293 & .277 & & & & \\
\hline & (.167) & (.164) & $(.223)$ & $(.220)$ & (.291) & $(.293)$ & $(.411)$ & $(.404)$ & (.187) & (.183) & $(.265)$ & $(.265)$ & & & & \\
\hline \multirow{2}{*}{$\begin{array}{l}\text { Single parent } \\
\text { (ref. married parent) }\end{array}$} & $.190^{*}$ & $.288^{* *}$ & $.179 \dagger$ & $.298^{*}$ & .004 & -.027 & -.016 & .076 & $.431^{* *}$ & $.727^{* * *}$ & $.338^{*}$ & $.520^{* *}$ & .062 & -.022 & -.050 & .061 \\
\hline & (.091) & $(.110)$ & (.108) & $(.130)$ & $(.161)$ & (.192) & (.193) & $(.234)$ & $(.138)$ & $(.146)$ & $(.148)$ & $(.173)$ & $(.150)$ & (.194) & $(.204)$ & $(.226)$ \\
\hline \multirow[t]{2}{*}{ Extended kin } & $.262^{* *}$ & $399^{* * * *}$ & .173 & $.338^{*}$ & $.302 \uparrow$ & .241 & .315 & .437 & $.262^{*}$ & $.564^{* * * *}$ & .127 & .313 & .204 & .102 & .090 & .226 \\
\hline & $(.088)$ & (.112) & $(.111)$ & $(.145)$ & $(.155)$ & $(.243)$ & $(.195)$ & $(.294)$ & $(.132)$ & $(.143)$ & $(.158)$ & $(.195)$ & $(.155)$ & $(.217)$ & $(.225)$ & $(.278)$ \\
\hline \multirow[t]{2}{*}{ Single-parent*Extended } & & $-.340 \dagger$ & & $-.409 \dagger$ & & .114 & & -.226 & & $-1.11^{* * *}$ & & $-.684^{*}$ & & .230 & & -.305 \\
\hline & & $(.186)$ & & $(.232)$ & & $(.343)$ & & $(.423)$ & & $(.269)$ & & $(.302)$ & & $(.302)$ & & $(.449)$ \\
\hline \multirow[t]{2}{*}{ Intercept } & $1.251^{* * *}$ & $1.210^{* * *}$ & $2.229^{* * *}$ & $2.180^{* * *}$ & $1.632^{*}$ & $1.660^{*}$ & $3.079^{* * *}$ & $3.022^{* * *}$ & $.880^{* *}$ & $.768^{* *}$ & .590 & .521 & $1.931^{* * *}$ & $1.981^{* * *}$ & $3.596^{* * *}$ & $3.531^{* * *}$ \\
\hline & $(.262)$ & $(.260)$ & $(.360)$ & $(.358)$ & $(.672)$ & $(.687)$ & $(.821)$ & $(.838)$ & $(.303)$ & $(.282)$ & $(.427)$ & $(.422)$ & $(.448)$ & $(.471)$ & $(.417)$ & $(.410)$ \\
\hline $\mathrm{R}^{2}$ & .189 & .192 & .101 & .104 & .130 & .131 & .080 & .081 & .183 & .219 & .161 & .170 & .062 & .065 & .067 & .071 \\
\hline Unweighted $\mathrm{N}$ & 1552 & 1552 & 1552 & 1552 & 568 & 568 & 568 & 568 & 664 & 664 & 664 & 664 & 320 & 320 & 320 & 320 \\
\hline
\end{tabular}

Note: $* * *: p<.0001, * *: p<.01, *: p<.05, \uparrow: p<.10$ 